\title{
Biological conversion of aromatic monolignol compounds by a Pseudomonas isolate from sediments of the Baltic Sea
}

\author{
Krithika Ravi $^{1 \dagger}$, Javier García-Hidalgo ${ }^{2^{*}+}$ (10, Matthias Nöbel ${ }^{1}$, Marie F. Gorwa-Grauslund ${ }^{2}$ and Gunnar Lidén ${ }^{1}$
}

\begin{abstract}
Bacterial strains were isolated from the sediments of the Baltic Sea using ferulic acid, guaiacol or a lignin-rich softwood waste stream as substrate. In total nine isolates were obtained, five on ferulic acid, two on guaiacol and two on a lignin-rich softwood stream as a carbon source. Three of the isolates were found to be Pseudomonas sp. based on 165 rRNA sequencing. Among them, isolate 9.1, which showed the fastest growth in defined M9 medium, was tentatively identified as a Pseudomonas deceptionensis strain based on the gyrB sequencing. The growth of isolate 9.1 was further examined on six selected lignin model compounds (ferulate, $p$-coumarate, benzoate, syringate, vanillin and guaiacol) from different upper funneling aromatic pathways and was found able to grow on four out of these six compounds. No growth was detected on syringate and guaiacol. The highest specific growth and uptake rates were observed for benzoate $\left(0.3 \mathrm{~h}^{-1}\right.$ and $\left.4.2 \mathrm{mmol} \mathrm{g}_{\mathrm{CDw}}^{-1} \mathrm{~h}^{-1}\right)$ whereas the lowest were for the compounds from the coniferyl branch. Interestingly, several pathway intermediates were excreted during batch growth. Vanillyl alcohol was found to be excreted during growth on vanillin. Several other intermediates like cis,cis-muconate, catechol, vanillate and 4-hydroxybenzoate from the known bacterial catabolic pathways were excreted during growth on the model compounds.
\end{abstract}

Keywords: Sediment isolates, Pseudomonas, Bacterial aromatic catabolism, Monolignols, Vanillyl alcohol

\section{Introduction}

Lignin is one of the most plentiful biopolymers on Earth. It is a complex alkyl-aromatic heteropolymer found in the plant cell wall, which provides strength and protection to terrestrial plants. Currently, technical lignin is produced from either the pulp/paper industries and/or cellulosic ethanol biorefineries, where it is mainly used as an energy source to produce steam and electricity. Lignin is underexploited as a chemical feedstock because of its heterogeneity and intractable structure (Ayyachamy et al. 2013). The valorization of lignin to produce renewable fuels and chemicals is important to further develop the biorefineries (Beckham et al. 2016; Camarero et al. 2014; Rodriguez et al. 2017). To allow lignin to be used

\footnotetext{
${ }^{*}$ Correspondence: javier.garcia_hidalgo@tmb.lth.se

${ }^{\dagger}$ Krithika Ravi and Javier García-Hidalgo contributed equally to this work

2 Department of Chemistry, Applied Microbiology, Lund University, P.O.

Box 124, 22100 Lund, Sweden

Full list of author information is available at the end of the article
}

as a substrate for bioconversion, a depolymerization step is essential to generate a combination of monomeric, dimeric and oligomeric lignin-based compounds (Rinaldi et al. 2016; Xu et al. 2014). These can be further catabolized into various bio-based compounds of economic value for lignocellulosic biorefineries (Abdelaziz et al. 2016; Salvachúa et al. 2015).

Lignin in nature is degraded mainly by extracellular peroxidases and laccases, secreted by white-rot and brown-rot fungi. The action of these enzymes on lignin results in a diverse range of low molecular weight aromatic fragments (Martínez et al. 2005). Due to the widespread availability of these aromatic molecules in the environment, several microbes have developed catabolic pathways for these (Makela et al. 2015). There have been many studies on a variety of fungal species, which can utilize lignin-related compounds with the help of redox mediators (Martínez et al. 2005). However, their commercial application is limited by slow growth rates and 
difficulties related to fungal genetic manipulation (Bugg et al. 2011a).

In addition to fungi, there are several bacterial species capable of catabolizing lignin or lignin-related aromatic compounds (Brown and Chang 2014; Bugg et al. 2011b). Bacteria have certain benefits over fungi, e.g. easy genetic engineering, fast growth and ease of cultivation. Reported bacteria with ability to convert aromatics include Pseudomonas putida KT2440 (Jiménez et al. 2002; Ravi et al. 2017), Cupriavidus necator JMP134 (Pérez-Pantoja et al. 2008), Rhodococcus opacus (Zhao et al. 2016), Rhodococcus jostii RHA1 (Ahmad et al. 2011), Acinetobacter baylyi ADP1 (Barbe et al. 2004), Amycolatopsis sp. 75iv2 (Brown et al. 2011), Sphingomonas sp. strain SYK-6 (Masai et al. 2007) and Streptomyces viridosporus T7A (Ramachandra et al. 1988). Most likely, there are other bacteria with aromatic metabolizing capacities, which are yet to be identified. Recently, there has been an extensive search for more bacterial species from several natural or manmade environments, which exhibit certain lignin-degrading abilities thanks to the secretion of oxidoreductases, etherases and other enzymes (Picart et al. 2016; Taylor et al. 2012). Some of the reported organisms are, e.g. Klebsiella and Pseudomonas spp. from compost samples (Ravi et al. 2017), Cupriavidus basilensis B-8 (Shi et al. 2013) and Comamonas sp. B-9 from eroded bamboo slips (Chen et al. 2012), Bacillus pumilus and Bacillus atrophaeus from biodiversity-rich rainforest soil (Huang et al. 2013) and Trabulsiella sp. isolated from termite gut (Suman et al. 2016). It is essential not only to isolate these organisms, but also to characterize their inherent aromatic metabolism in order to assess their potential-as hosts or donor of pathways-for lignin valorization.

In the present study, our initial aim was to isolate and identify easily culturable bacterial species from sediments in the Baltic Sea, close to the wastewater stream of a sulfite pulp production plant in northern Sweden (Kramfors). In this environment, lignin-rich residuals were deposited and accumulated between 1907 and 1977 (Apler et al. 2014). Lignin-enriched wastewater effluents have a damaging effect to the aquatic ecosystems because of their toxic chemical compounds and also due to the recalcitrance of this polymer in natural environments (Berryman et al. 2004). Therefore bacterial species present in such polluted sediments are likely to possess aromatic metabolic capacities, and hence are interesting to investigate (Priyadarshinee et al. 2016). The second objective was to further examine the metabolism of aromatic compounds by the most interesting isolates. In particular, one of the isolates, identified as Pseudomonas sp. 9.1 was grown on six lignin model compounds (ferulate, $p$-coumarate, benzoate, syringate, vanillin and guaiacol) representing the main branches of the upper funneling catabolic pathways (Fig. 1) and specific growth rates, specific uptake rates and by-product formation from the aromatic compounds were quantified. The selected isolate, under the same initial aromatic compounds concentration, was found to behave quite differently from the previously studied $P$. putida KT2440 (Ravi et al. 2017) since it excreted several pathway intermediates. Further experiments were conducted with the excreted intermediates and the conversion rates of various upper funneling branches leading to $\beta$-ketoadipate pathway were assessed.

\section{Materials and methods \\ Cultivation media}

M9 mineral medium was used for all the experiments (Sambrook and Russell 2001). The composition is as follows: $6 \mathrm{~g} \mathrm{~L}^{-1}$ disodium phosphate, $3 \mathrm{~g} \mathrm{~L}^{-1}$ monopotassium phosphate, $0.5 \mathrm{~g} \mathrm{~L}^{-1}$ sodium chloride, $1 \mathrm{~g} \mathrm{~L}^{-1}$ ammonium chloride, $2 \mathrm{mM}$ magnesium sulfate, $100 \mu \mathrm{M}$ calcium chloride with $10 \mathrm{~mL} \mathrm{~L}^{-1}$ trace elements solution (Pfennig and Lippert 1966). The $\mathrm{pH}$ of the final medium was adjusted to 7 . All the chemicals and materials used were purchased from Sigma-Aldrich (St. Louis, USA) or VWR (West Chester, PA, USA). Sterile conditions were maintained by either autoclavation or sterile filtration.

\section{Strains}

In this study, nine bacterial strains were isolated from sediments of the Baltic Sea. The isolate used in the detailed characterization experiments, namely Pseudomonas sp. 9.1 was deposited in the DSMZ (German Collection of Microorganisms and Cell Cultures), with accession code DSM 105530. All the strains isolated in this work (see Table 1) are available for research purposes upon request.

\section{Isolation and identification of bacterial strains from the Baltic Sea sediments}

An enrichment culture protocol was developed with the purpose of isolating mesophilic culturable bacteria from Baltic Sea sediments. These fiber-rich sediments were obtained in the vicinity of a pulp and paper mill located in the northern Baltic coast of Sweden. The sludgy sediment sample (approximately $1 \mathrm{~g}$ ) was initially washed with $4 \mathrm{~mL}$ of $0.8 \%$ sterile $\mathrm{NaCl}$ solution by vigorous vortexing, and after $5 \mathrm{~min}$ of settling the supernatant was used to inoculate culture plates. As a first stage prior to the screening with model compounds, a revitalization step in nutrient agar plates was included to allow dormant bacteria to revive after a freezing period. In order to enrich exclusively the bacteria present in this environment, cycloheximide was added to the screening cultures to inhibit the growth of fungi or other eukaryotes 


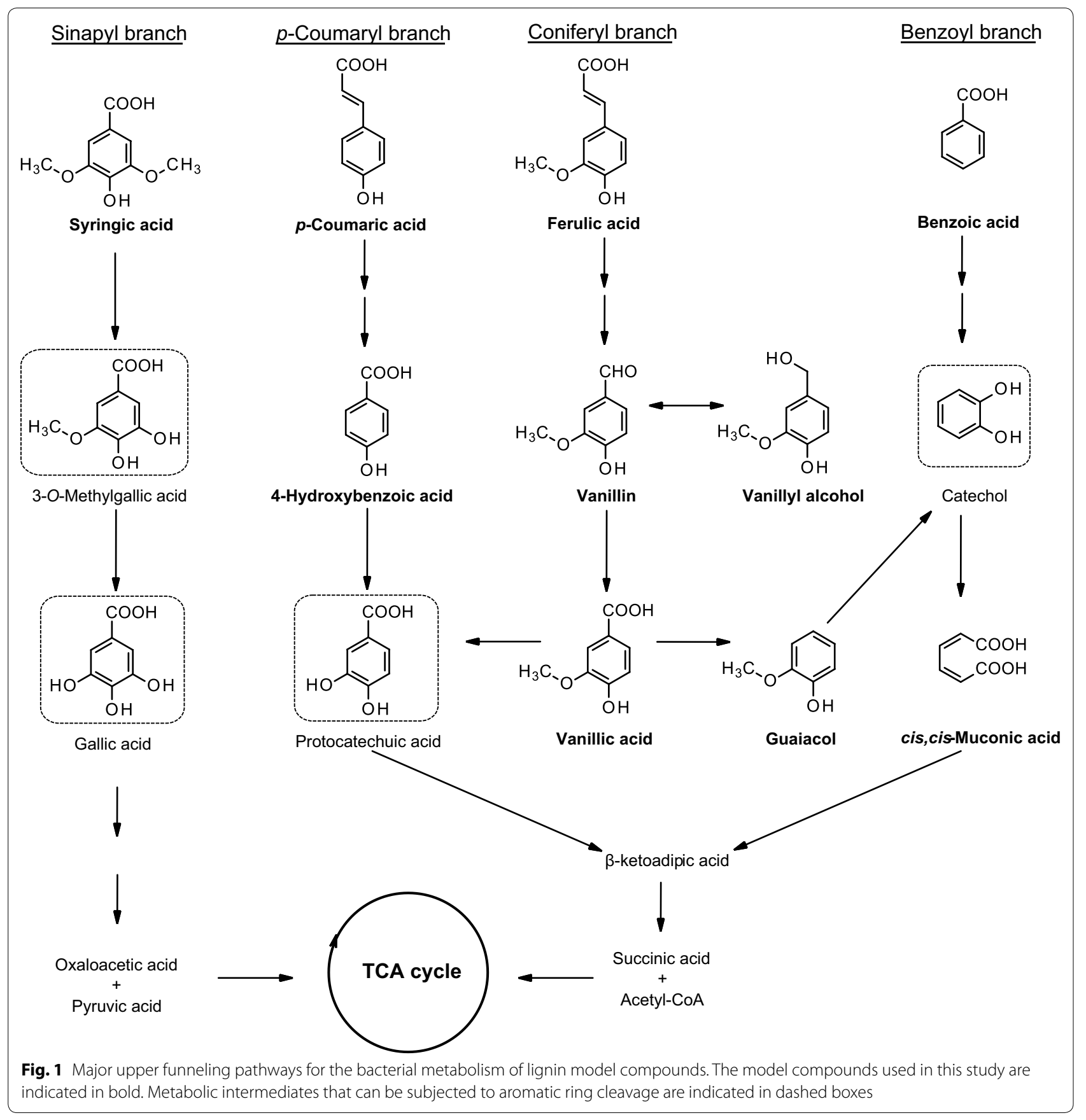

present in the sample. A number of different bacterial species were isolated by successive streaking on mineral M9 medium plates supplemented with different ligninrelated model compounds, namely ferulic acid and guaiacol or lignin-rich softwood pulping streams. Isolates were grown in liquid LB medium or nutrient broth overnight prior to freezing and storage at $-80^{\circ} \mathrm{C}$.

Identification of the bacterial isolates was carried out by PCR amplification and sequencing of the $16 \mathrm{~S}$ rRNA using genomic DNA of the isolates as template, exactly as described in Ravi et al. 2017. Further taxonomic study of the isolates belonging to the genus Pseudomonas was done by partial gyrB gene PCR amplification, using Phusion Hot Start II High-Fidelity DNA Polymerase (Thermo Scientific), the degenerate primers gyrB $\mathrm{Fw}$ ( $5^{\prime}$ GGGA ACAGACBTACGTBCACGGYGTT $\left.3^{\prime}\right)$ and gyrB Rv (5' GCTTTACGBGCSGCYTCACG $3^{\prime}$ ) and following this PCR program: Initial denaturation at $98{ }^{\circ} \mathrm{C}$ for $7 \mathrm{~min}$, 
Table 1 Identification of the bacterial isolates by 16 S rRNA sequencing

\begin{tabular}{|c|c|c|c|c|c|c|c|c|c|}
\hline \multirow[t]{2}{*}{ Isolate } & \multicolumn{3}{|l|}{ BLAST } & \multicolumn{3}{|l|}{ EzBioCloud } & \multirow{2}{*}{$\begin{array}{l}\text { Taxonomic } \\
\text { group }\end{array}$} & \multirow[t]{2}{*}{ Gram } & \multirow[t]{2}{*}{ Isolated from } \\
\hline & Species & $\begin{array}{l}\text { Query cover } \\
\text { (\%) }\end{array}$ & Identity (\%) & Species & Similarity (\%) & $\begin{array}{l}\text { Complete- } \\
\text { ness (\%) }\end{array}$ & & & \\
\hline \multirow[t]{3}{*}{8.1} & $\begin{array}{l}\text { Pseudomonas } \\
\text { donghuensis } \\
\text { HYS (T) }\end{array}$ & 100 & 98 & $\begin{array}{l}\text { Pseudomonas } \\
\text { alcaligenes } \\
\text { TPID2/ } \\
\text { JYOC } 5\end{array}$ & 98.86 & 100 & $\begin{array}{l}\text { Y-proteobacteria, } \\
\text { Pseudomonads }\end{array}$ & - & Ferulic acid \\
\hline & $\begin{array}{l}\text { Pseudomonas } \\
\text { alkylphenolia } \\
\text { KL28 (T) }\end{array}$ & 100 & 98 & $\begin{array}{l}\text { Pseudomonas } \\
\text { alkylphenolia } \\
\mathrm{KL} 28(\mathrm{~T})\end{array}$ & 98.37 & 100 & & & \\
\hline & $\begin{array}{l}\text { Pseudomonas } \\
\text { lutea OK2 (T) }\end{array}$ & 100 & 98 & $\begin{array}{l}\text { Pseudomonas } \\
\text { donghuensis } \\
\text { HYS (T) }\end{array}$ & 98.37 & 100 & & & \\
\hline \multirow[t]{3}{*}{8.2} & $\begin{array}{l}\text { Lelliottia } \\
\text { amnigena } \\
\text { JCM1237 (T) }\end{array}$ & 99 & 99 & $\begin{array}{l}\text { Lelliottia amni- } \\
\text { gena NBRC } \\
105700(T)\end{array}$ & 99.72 & 100 & $\begin{array}{l}\text { Y-proteobacteria } \\
\text { Enterobacte- } \\
\text { riaceae }\end{array}$ & - & \\
\hline & $\begin{array}{c}\text { Kluyvera inter- } \\
\text { media } 256\end{array}$ & 99 & 99 & $\begin{array}{c}\text { Kluyvera inter- } \\
\text { media ATCC } \\
33110(\mathrm{~T})\end{array}$ & 98.86 & 100 & & & \\
\hline & $\begin{array}{c}\text { Kluyvera inter- } \\
\text { media NBRC } \\
102594(T)\end{array}$ & 99 & 99 & $\begin{array}{c}\text { Raoultella ter- } \\
\text { rigena ATCC } \\
33257 \text { (T) }\end{array}$ & 98.86 & 99.3 & & & \\
\hline \multirow[t]{3}{*}{9.1} & $\begin{array}{l}\text { Pseudomonas } \\
\text { deceptionen- } \\
\text { sis M1 (T) }\end{array}$ & 99 & 99 & $\begin{array}{l}\text { Pseudomonas } \\
\text { weihen- } \\
\text { stephanensis } \\
\text { DSM29166 } \\
\text { (T) }\end{array}$ & 99.93 & 100 & $\begin{array}{l}\text { y-proteobacteria, } \\
\text { Pseudomonads }\end{array}$ & - & \\
\hline & $\begin{array}{l}\text { Pseudomonas } \\
\text { fragi ATCC } \\
4973\end{array}$ & 99 & 99 & $\begin{array}{l}\text { Pseudomonas } \\
\text { deceptionen- } \\
\text { sis M1 (T) }\end{array}$ & 99.79 & 100 & & & \\
\hline & $\begin{array}{l}\text { Pseudomonas } \\
\text { psychrophila } \\
\text { E-3(T) }\end{array}$ & 99 & 99 & $\begin{array}{l}\text { Pseudomonas } \\
\text { psychrophila } \\
\text { E-3 (T) }\end{array}$ & 99.64 & 100 & & & \\
\hline \multirow[t]{3}{*}{9.2} & $\begin{array}{l}\text { Pseudomonas } \\
\text { umsongensis } \\
\text { Ps 3-10 (T) }\end{array}$ & 99 & 99 & $\begin{array}{l}\text { Pseudomonas } \\
\text { moorei } \\
\text { RW10 (T) }\end{array}$ & 99.78 & 100 & & - & \\
\hline & $\begin{array}{l}\text { Pseudomonas } \\
\text { baetica a390 } \\
\text { (T) }\end{array}$ & 99 & 99 & $\begin{array}{l}\text { Pseudomonas } \\
\text { mohnii Ipa-2 } \\
\text { (T) }\end{array}$ & 99.64 & 100 & & & \\
\hline & $\begin{array}{l}\text { Pseudomonas } \\
\text { vancouver- } \\
\text { ensis DhA-51 } \\
\text { (T) }\end{array}$ & 99 & 99 & $\begin{array}{l}\text { Pseudomonas } \\
\text { umsongensis } \\
\text { Ps 3-10 (T) }\end{array}$ & 99.58 & 99.7 & & & \\
\hline \multirow[t]{3}{*}{19} & $\begin{array}{l}\text { Nocardia } \\
\quad \text { coeliaca DSM } \\
44595(\mathrm{~T})\end{array}$ & 99 & 99 & $\begin{array}{l}\text { Rhodococcus } \\
\text { erythropolis } \\
\text { NBRC } 15567 \\
\text { (T) }\end{array}$ & 99.71 & 100 & $\begin{array}{l}\text { Actinobacteria, } \\
\text { Nocardiaceae }\end{array}$ & + & \\
\hline & $\begin{array}{l}\text { Rhodococcus } \\
\text { erythropolis } \\
\text { N11 }\end{array}$ & 99 & 99 & $\begin{array}{l}\text { Rhodococcus } \\
\text { qingshengii } \\
\text { JCM } 15477 \\
\text { (T) }\end{array}$ & 99.07 & 100 & & & \\
\hline & $\begin{array}{c}\text { Rhodococcus } \\
\text { jialingiae } \\
\text { djl-6-2 (T) }\end{array}$ & 99 & 99 & $\begin{array}{l}\text { Rhodococcus } \\
\text { degradans } \\
\text { CCM } 4446 \\
\text { (T) }\end{array}$ & 99.07 & 100 & & & \\
\hline
\end{tabular}


Table 1 continued

\begin{tabular}{|c|c|c|c|c|c|c|c|c|c|}
\hline \multirow[t]{2}{*}{ Isolate } & \multicolumn{3}{|l|}{ BLAST } & \multicolumn{3}{|l|}{ EzBioCloud } & \multirow{2}{*}{$\begin{array}{l}\text { Taxonomic } \\
\text { group }\end{array}$} & \multirow[t]{2}{*}{ Gram } & \multirow[t]{2}{*}{ Isolated from } \\
\hline & Species & $\begin{array}{l}\text { Query cover } \\
\text { (\%) }\end{array}$ & Identity (\%) & Species & Similarity (\%) & $\begin{array}{l}\text { Complete- } \\
\text { ness (\%) }\end{array}$ & & & \\
\hline \multirow[t]{3}{*}{47.1} & $\begin{array}{l}\text { Acinetobacter } \\
\text { Iwoffii DSM } \\
2403(\mathrm{~T})\end{array}$ & 99 & 99 & $\begin{array}{l}\text { Acinetobacter } \\
\text { Iwoffii NIPH } \\
715\end{array}$ & 98.87 & 100 & \multirow{3}{*}{$\begin{array}{l}\text { Y-proteobacteria, } \\
\text { Pseudomon- } \\
\text { ads, Moraxel- } \\
\text { laceae }\end{array}$} & \multirow[t]{3}{*}{-} & \multirow[t]{6}{*}{ Guaiacol } \\
\hline & $\begin{array}{l}\text { Acinetobacter } \\
\text { albensis ANC } \\
4874(\mathrm{~T})\end{array}$ & 99 & 99 & $\begin{array}{l}\text { Acinetobacter } \\
\text { Iwoffii NCTC } \\
5866(\mathrm{~T})\end{array}$ & 98.58 & 100 & & & \\
\hline & $\begin{array}{l}\text { Prolinoborus } \\
\text { fasciculus CIP } \\
103579(\mathrm{~T})\end{array}$ & 98 & 99 & $\begin{array}{l}\text { Acinetobacter } \\
\text { albensis ANC } \\
4874\end{array}$ & 98.44 & 100 & & & \\
\hline \multirow[t]{3}{*}{47.2} & $\begin{array}{l}\text { Lysinibacillus } \\
\text { macroides } \\
\text { LMG } 18474 \\
(\mathrm{~T})\end{array}$ & 100 & 99 & $\begin{array}{l}\text { Lysinibacillus } \\
\text { macroides } \\
\text { DSM } 54 \text { (T) }\end{array}$ & 99.58 & 100 & \multirow[t]{9}{*}{$\begin{array}{l}\text { Firmicutes, Bacil- } \\
\text { laceae }\end{array}$} & \multirow[t]{3}{*}{+} & \\
\hline & $\begin{array}{l}\text { Lysinibacillus } \\
\text { boronitoler- } \\
\text { ans NBRC } \\
103108(T)\end{array}$ & 100 & 99 & $\begin{array}{l}\text { Lysinibacillus } \\
\text { xylanilyticus } \\
\text { DSM } 23493 \\
\text { (T) }\end{array}$ & 99.37 & 100 & & & \\
\hline & $\begin{array}{l}\text { Lysinibacillus } \\
\text { pakistanensis } \\
\text { NCCP-54 (T) }\end{array}$ & 99 & 99 & $\begin{array}{l}\text { Lysinibacillus } \\
\text { pakistanensis } \\
\text { JCM } 18776 \\
\text { (T) }\end{array}$ & 99.30 & 100 & & & \\
\hline \multirow[t]{3}{*}{49} & $\begin{array}{l}\text { Bacillus licheni- } \\
\text { formis DSM } \\
13(T)\end{array}$ & 100 & 99 & $\begin{array}{l}\text { Bacillus licheni- } \\
\text { formis ATCC } \\
14580(T)\end{array}$ & 99.76 & 100 & & \multirow[t]{3}{*}{+} & \multirow[t]{6}{*}{$\begin{array}{l}\text { Softwood } \\
\text { stream }\end{array}$} \\
\hline & $\begin{array}{c}\text { Bacillus sono- } \\
\text { rensis NBRC } \\
101234(T)\end{array}$ & 100 & 99 & $\begin{array}{l}\text { Bacillus parali- } \\
\text { cheniformis } \\
\text { KJ-16 (T) }\end{array}$ & 99.76 & 86.4 & & & \\
\hline & $\begin{array}{l}\text { Bacillus aerius } \\
24 \mathrm{~K}(\mathrm{~T})\end{array}$ & 100 & 99 & $\begin{array}{c}\text { Bacillus sono- } \\
\text { rensis NBRC } \\
101234(\mathrm{~T})\end{array}$ & 99.61 & 100 & & & \\
\hline \multirow[t]{3}{*}{$3 B$} & $\begin{array}{l}\text { Bacillus safensis } \\
\text { NBRC } \\
100820(T)\end{array}$ & 100 & 99 & $\begin{array}{l}\text { Bacillus safensis } \\
\text { FO-36b (T) }\end{array}$ & 100 & 100 & & \multirow[t]{3}{*}{+} & \\
\hline & $\begin{array}{l}\text { Bacillus pumi- } \\
\text { lus NBRC } \\
12092(T)\end{array}$ & 100 & 99 & $\begin{array}{l}\text { Bacillus } \\
\text { australimaris } \\
\text { NH7I_1 (T) }\end{array}$ & 99.86 & 100 & & & \\
\hline & $\begin{array}{l}\text { Bacillus aerius } \\
24 \mathrm{~K}(\mathrm{~T})\end{array}$ & 100 & 99 & $\begin{array}{l}\text { Bacillus zhang- } \\
\text { zhouensis } \\
\text { DW5-4 (T) }\end{array}$ & 99.79 & 100 & & & \\
\hline
\end{tabular}

Type strains are indicated with $(\mathrm{T})$

30 cycles of: (denaturation at $98{ }^{\circ} \mathrm{C}$ for $10 \mathrm{~s}$, annealing at $67{ }^{\circ} \mathrm{C}$ for $20 \mathrm{~s}$, extension at $72{ }^{\circ} \mathrm{C}$ for $16 \mathrm{~s}$ ) and final extension at $72{ }^{\circ} \mathrm{C}$ for $5 \mathrm{~min}$. Amplified DNA fragments of around $700 \mathrm{bp}$ were purified with GeneJET PCR Purification Kit (Thermo Scientific) and sent for sequencing with the same primers to Eurofins Genomics (Ebersberg, Germany).

The obtained 16S rRNA and gyrB sequences from bacterial isolates were deposited in the European Nucleotide Archive (ENA), with the following accession codes: LT891931 (16S isolate 8.1), LT891932 (16S isolate 8.2), LT891933 (16S isolate 9.1), LT891934 (16S isolate 9.2), LT891935 (16S isolate 19), LT891936 (16S isolate 47.1),
LT891937 (16S isolate 47.2), LT891938 (16S isolate 49), LT891939 (16S isolate 3B), LT891940 ( $g y r B$ isolate 8.1), LT891941 ( $g y r B$ isolate 9.1) and LT891942 ( $g y r B$ isolate 9.2). Retrieved sequences were submitted to the taxonomic identification servers BLAST (16S ribosomal RNA database for $16 \mathrm{~S}$ rRNA or Nucleotide collection $\mathrm{nr} / \mathrm{nt}$ for $\operatorname{gyrB}$ sequences) and EzBioCloud (http://www.ezbiocloud.net/identify) (Yoon et al. 2017).

\section{Shake flask fermentations}

Bacterial cultures from glycerol stocks were streaked on LB plates to obtain single colonies, and pre-cultures $(25 \mathrm{~mL})$ were started by inoculating a single colony of 
microorganism from the LB plate to M9 medium containing $10 \mathrm{~g} \mathrm{~L}^{-1}$ glucose. Cultivations were made in $250 \mathrm{~mL}$ shake flasks with $25 \mathrm{~mL}$ culture volume, placed in an orbital shaker operating at $180 \mathrm{rpm}$ to uphold aerobic conditions at a temperature of $27^{\circ} \mathrm{C}$. After about $16 \mathrm{~h}$ of growth on glucose, cells were harvested and washed with sterile saline solution. Subsequently, the cells were transferred into other $250 \mathrm{~mL}$ flasks containing $50 \mathrm{~mL} \mathrm{M9}$ medium with $5 \mathrm{mM}$ of either ferulate, $p$-coumarate, benzoate, syringate, vanillin, guaiacol, vanillate, 4-hydroxybenzoate, vanillyl alcohol or cis,cis-muconate. These flasks were also maintained at $27^{\circ} \mathrm{C}$ and $180 \mathrm{rpm}$. The inoculation aimed to achieve an initial OD of around 0.1. In case the organism did not start growing until around $200 \mathrm{~h}$, the experiments were repeated with an initial OD of 0.5. All shake flask experiments were conducted in duplicates.

Samples were withdrawn at regular intervals to measure the optical density (OD) spectrophotometrically at $620 \mathrm{~nm}$. The samples were diluted to stay in the linear range of absorbance (0.03-0.3). After every sampling, the cells were removed by centrifugation at 12,300 $g$ for $3 \mathrm{~min}$ and the supernatants were filtered $(0.2 \mu \mathrm{m}$ pore size $)$ and then stored at $-20{ }^{\circ} \mathrm{C}$ for UHPLC (Ultra High-Performance Liquid Chromatography) analysis.

\section{Determination of rates and yields}

The measured optical density was recalculated to biomass concentration using a response factor of 0.62 , determined from measured final biomass dry weight. Biomass yield $\left[\mathrm{g}(\mathrm{g})^{-1}\right.$ or $\left.\left.\mathrm{g}(\mathrm{mmol})^{-1}\right)\right]$ was calculated by subtracting the initial biomass supplied from the final biomass formed, divided by the total mass or amount of carbon substrate consumed. Specific growth rates were calculated by plotting the natural logarithm of biomass over time in its exponential phase. The specific substrate uptake rates were calculated for different time intervals from measured substrate consumption divided by the average biomass in that time interval. The overall specific substrate uptake rate was calculated as the average of determined specific substrate uptake rates during exponential growth.

\section{UHPLC analysis}

A Waters Acquity UPLC system (Milford, USA) coupled with a photodiode array detector was used to perform the analysis of aromatic compounds. The type of column used for separation was a Waters Acquity UPLC BEH (Ethylene Bridged Hybrid) C18 column with an internal diameter of $2.1 \mathrm{~mm}, 100 \mathrm{~mm}$ length and $1.7 \mu \mathrm{m}$ particle size. The temperature of the column was maintained at $47^{\circ} \mathrm{C}$. The mobile phases used were the binary solvent system consisting of fraction A (3\% acetonitrile, $2 \%$ acetic acid, 95\% MilliQ-water) and fraction B (85\% acetonitrile, $2 \%$ acetic acid, $13 \%$ MilliQ-water). The sample injection volume was $2.5 \mu \mathrm{L}$.

The UPLC analysis method was adapted from Schwarz et al. (2009) with some modifications. To avoid high backpressure the flow rate was set to $0.6 \mathrm{~mL} / \mathrm{min}$. To compensate for the lower flow rate, the gradient time was extended to 11.5 min with: $0 \mathrm{~min}, 100 \%$ A; 5 min, $90 \%$ A; $7 \mathrm{~min}, 90 \%$ A; $11.5 \mathrm{~min}, 25 \%$ A. Finally, the column was washed with $100 \% \mathrm{~B}$ and $100 \% \mathrm{~A}$ for 5 min each. Analysis data was reviewed with Empower 3 Chromatography Data Software. Peaks were identified and quantified according to the area under the curve against their respective calibration standards.

\section{Orbitrap mass spectrometry}

Orbitrap mass spectrometer was used to identify and confirm the excreted metabolic intermediates. Multiple stage tandem mass spectrometry $\left(\mathrm{MS}^{\mathrm{n}}\right)$ experiments were performed on LTQ Velos Pro system equipped with a heated electrospray ionization source (HESI) (Thermo Fisher Scientific, Bremen, Germany). Standards and samples were infused with a syringe at a flow rate of $20 \mu \mathrm{L} \mathrm{min}{ }^{-1}$ using methanol as solvent. The HESI source was operated in negative mode using an ion source temperature of $50{ }^{\circ} \mathrm{C}$, a capillary voltage of $2.5 \mathrm{kV}$ and a sheath gas flow of rate of 10 arbitrary units. The capillary temperature was set to $275{ }^{\circ} \mathrm{C}$. The $\mathrm{MS}^{\mathrm{n}}$ experiments were performed using the Orbitrap mass analyzer at a resolution of 100,000 in a mass range of $m / z 50-500$. Collision induced dissociation was performed with a normalized collision energy of 35 . The instrument was controlled by Xcalibur 2.2 software.

\section{Results}

\section{Isolation and identification of bacterial strains from Baltic} Sea sediments

A sample of sediments from a shore next to an old pulp and paper mill was analyzed in order to detect and isolate bacterial strains able to thrive in this type of heavily polluted environment. To this end, an enrichment culture was carried out in a minimal medium with different lignin-related aromatic substrates (ferulate, guaiacol and lignin-enriched pulping stream form softwood) as the sole source of carbon and energy. The bacterial colonies grown in these experiments were subsequently isolated by restreaking until obtaining pure cultures. The isolates found on guaiacol and softwood stream plates were tested for growth on ferulate, $p$-coumarate, benzoate, syringate and guaiacol in liquid shake flask cultures, however no growth was found (Additional file 1).

The isolates were identified by $16 \mathrm{~S}$ rRNA amplification and sequencing. Sequences were submitted to two 
Table 2 Identification of isolates from the genus Pseudomonas by partial gyrB sequencing

\begin{tabular}{|c|c|c|c|}
\hline & Species & Query cover (\%) & Identity (\%) \\
\hline \multirow[t]{4}{*}{ Isolate 8.1} & P. syringae pv. delphinii & 99 & 88 \\
\hline & P. syringae RM12EL_22A & 99 & 88 \\
\hline & P. viridiflava CFBP 1590 & 99 & 88 \\
\hline & $\begin{array}{l}\text { P. avellanae CIP } 105176 \\
\text { (Type strain) }\end{array}$ & 99 & 88 \\
\hline \multirow[t]{4}{*}{ Isolate 9.1} & P. fluorescens PF02 & 99 & 99 \\
\hline & P. fragi ATCC 27362 & 99 & 99 \\
\hline & $\begin{array}{l}\text { P. deceptionensis CECT } \\
7677 \text { (Type strain) }\end{array}$ & 99 & 94 \\
\hline & P. psychrophila BS3667 & 99 & 94 \\
\hline \multirow[t]{4}{*}{ Isolate 9.2} & $\begin{array}{l}\text { P. mohnii IPA-2 (Type } \\
\text { strain) }\end{array}$ & 98 & 97 \\
\hline & $\begin{array}{l}\text { P. moorei RW10 (Type } \\
\text { strain) }\end{array}$ & 98 & 97 \\
\hline & P. putida P-2 & 98 & 97 \\
\hline & $\begin{array}{l}\text { P. vancouverensis strain } \\
\text { BS3656 }\end{array}$ & 98 & 95 \\
\hline
\end{tabular}

different identification servers, obtaining the candidates shown in Table 1. Among the nine strains isolated in this work, three belong to the genus Pseudomonas, and the most likely identity of the rest of isolates is Lelliottia amnigena, the actinobacterium Rhodococcus erythropolis, Acinetobacter lwoffii, and three isolates from the Bacillaceae family, namely Lysinibacillus macroides, Bacillus licheniformis and Bacillus safensis. Since three out of nine identified isolates were found to belong to the genus Pseudomonas, and considering the difficulty of classifying Pseudomonas species, a more accurate taxonomic classification was attempted by partial amplification and sequencing of the $g y r B$ gene, which encodes a subunit of the DNA gyrase. The resulting sequences were aligned to the BLAST database, and the suggested candidates for each isolate are shown in Table 2.

As detailed in the following section, the isolate Pseudomonas sp. 9.1 exhibited the highest versatility in terms

Table 3 Assignment of Pseudomonas sp. isolate 9.1 to a species by alignment of $16 \mathrm{~S}$ and $g y r B$ sequences with those from the closest type strains

\begin{tabular}{|c|c|c|c|c|}
\hline \multirow[t]{2}{*}{ Type strain } & \multicolumn{2}{|c|}{ 16S rRNA } & \multicolumn{2}{|l|}{ gyrB } \\
\hline & Identity & Score & Identity & Score \\
\hline P. fluorescens & 98 & 2453 & 86 & 261 \\
\hline P. fragi & 99 & 2536 & 92 & 974 \\
\hline P. deceptionensis & 99 & 2560 & 94 & 1050 \\
\hline P.psychrophila & 99 & 2536 & 94 & 1044 \\
\hline P. weihenstephanensis & 99 & 2575 & 91 & 939 \\
\hline
\end{tabular}

The best hits in the database are highlighted in italics of utilization of lignin model compounds; therefore a more reliable assignment of this isolate to a particular species was performed. In order to achieve this, the partial $16 \mathrm{~S}$ and $\operatorname{gyr} B$ sequences were manually aligned exclusively to those of the type strains from the closest candidates. As shown in Table 3, the highest scored type strains were $P$. weihenstephanensis according to $16 \mathrm{~S}$ and $P$. deceptionensis according to gyrB. Taking into account the much higher discrimination power of the $g y r B$ analysis (Yamamoto and Harayama 1995), isolate 9.1 was tentatively identified as a Pseudomonas deceptionensis strain, a species belonging to the $P$. fluorescens group and $P$. frag $i$ subgroup according to Mulet et al. (2010).

\section{Growth characterization of Pseudomonas sp. isolate 9.1 on lignin model compounds}

Due to its fast growth on model compounds (ferulate, $p$-coumarate and benzoate) in M9 media during small scale cultivations (not shown), isolate 9.1 was selected for further characterization in the present study, and its growth on six lignin model compounds (ferulate, $p$-coumarate, benzoate, syringate, vanillin and guaiacol) was assessed.

Pseudomonas sp. isolate 9.1 was able to grow on four out of the six model compounds and use them as a sole source of carbon and energy (Fig. 2). No growth was observed on syringate or guaiacol. There was a lag phase of about $10 \mathrm{~h}$ for growth on ferulate, $p$-coumarate, benzoate but a substantially longer lag phase of almost $100 \mathrm{~h}$ for vanillin. Several compounds were found to be excreted during growth on $p$-coumarate, benzoate and vanillin. The excreted compounds were detected by UHPLC and were identified by orbitrap MS-MS, corresponded to intermediate compounds of the respective funneling pathway. 4-hydroxybenzoate from $p$-coumarate, catechol from benzoate, vanillyl alcohol and vanillate from vanillin were subsequently consumed, except for cis,cis-muconate (from benzoate), which remained unconsumed even after $20 \mathrm{~h}$ (Fig. 2). A diauxic growth pattern was observed when vanillin was provided as a carbon source (Fig. 2d). During the first phase, there was growth on vanillin and (partial) conversion of vanillin to vanillyl alcohol. In the second phase, the produced vanillyl alcohol was consumed. A small amount of vanillate production and subsequent consumption was also observed (Fig. 2d).

\section{Growth of Pseudomonas sp. isolate 9.1 on excreted intermediate compounds}

Further growth experiments were carried out on all the intermediate compounds found to be excreted during growth on the model compounds (4-hydroxybenzoate, vanillyl alcohol, vanillate and cis,cis-muconate) with the exception of catechol for which it was not possible to 

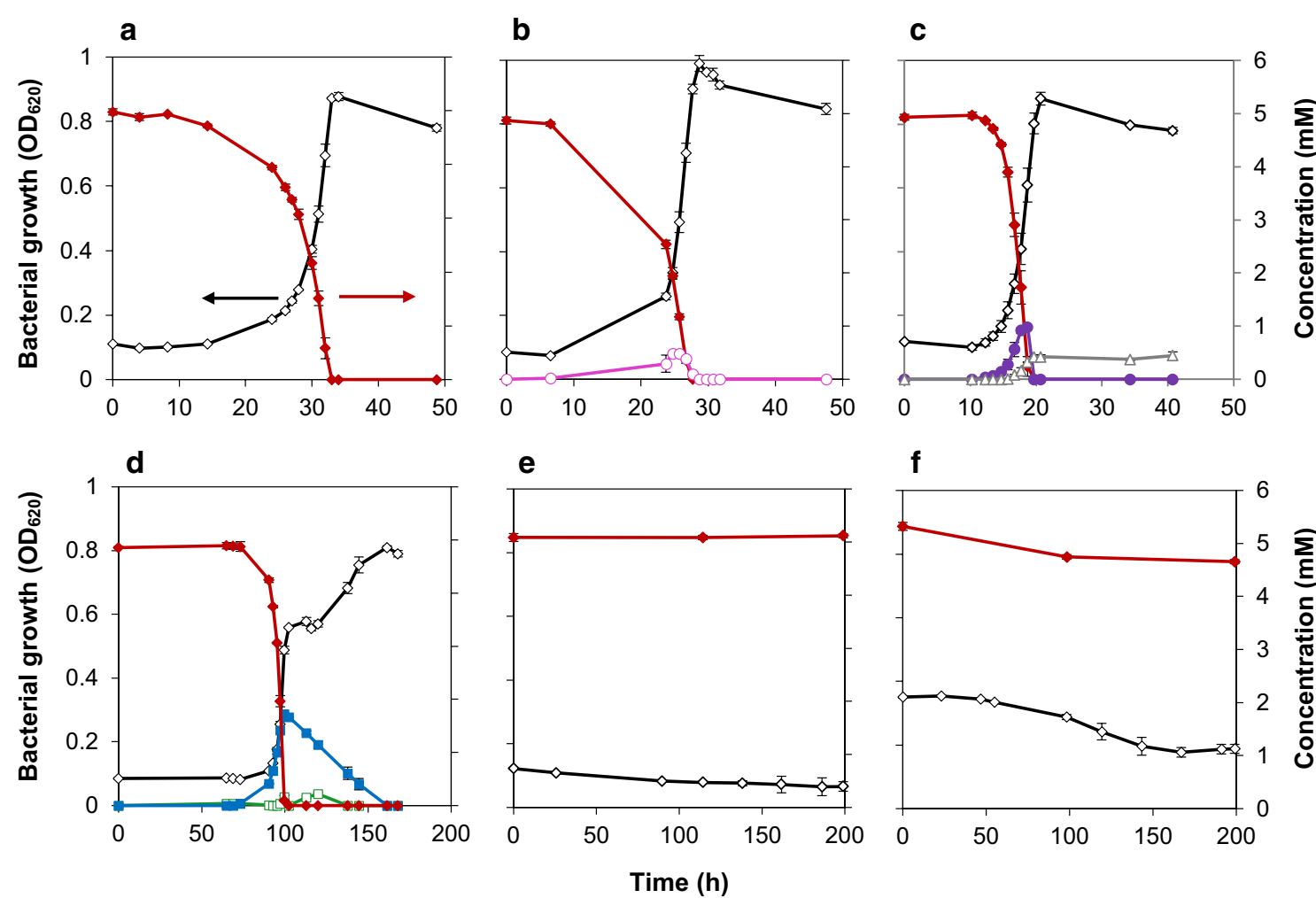

Fig. 2 Growth of Pseudomonas sp. isolate 9.1 on a ferulate, $\mathbf{b}$ p-coumarate, $\mathbf{c}$ benzoate, $\mathbf{d}$ vanillin, $\mathbf{e}$ syringate and $\mathbf{f}$ guaiacol as the only source of carbon. Experiments were performed in duplicates and the standard deviations are displayed with an error bar. The OD and model compounds concentration $(\mathrm{mM})$ are shown in black open diamond and red closed diamond respectively. The excreted intermediate compounds, if any, are also shown (Read from right axis). Pink open circle, 4-hydroxybenzoate; Violet closed circle, catechol; Grey open triangle, cis,cis-muconate; Blue closed square, vanillyl alcohol; green open square, vanillate

characterize growth since this compound was unstable in M9 medium.

Pseudomonas sp. isolate 9.1 grew directly on 4-HBA without any lag phase (Fig. 3). The growth on vanillate had a substantial lag phase-around $15 \mathrm{~h}$ and the growth on vanillyl alcohol did not start until more than $50 \mathrm{~h}$ had elapsed (Fig. 3), and in one case (duplicate) not before $75 \mathrm{~h}$. A small amount of excreted vanillin was detected during growth on vanillyl alcohol (Fig. 3c). Isolate 9.1 did not show any growth when cis,cis-muconate was given as a carbon source (data not shown). The compound was neither consumed nor converted into any other metabolite detected by UHPLC.

\section{Specific growth and uptake rates of Pseudomonas sp. isolate 9.1 on model compounds}

The specific growth rates, uptake rates and yields were calculated for Pseudomonas sp. isolate 9.1 on all the lignin model compounds used for growth (Table 4). The biomass yields were in the range of $0.43-0.76 \mathrm{~g}_{\mathrm{CDW}} \mathrm{g}^{-1}$. The highest specific growth and uptake rates were observed for benzoate $\left(0.3 \mathrm{~h}^{-1}\right.$ and $\left.4.2 \mathrm{mmol} \mathrm{g}_{\mathrm{CDW}}^{-1} \mathrm{~h}^{-1}\right)$ whereas the lowest were for vanillyl alcohol $\left(0.12 \mathrm{~h}^{-1}\right.$ and $1.67 \mathrm{mmol} \mathrm{g}_{\mathrm{CDW}}^{-1} \mathrm{~h}^{-1}$ ) respectively. The specific conversion rate of $p$-coumarate $\left(2.90 \mathrm{mmol} \mathrm{g}_{\mathrm{CDW}}^{-1} \mathrm{~h}^{-1}\right)$ was slightly higher than for the 4-HBA intermediate $\left(2.87 \mathrm{mmol} \mathrm{g}_{\mathrm{CDW}}^{-1} \mathrm{~h}^{-1}\right)$. This may explain the excretion of 4-HBA during growth on $p$-coumarate. The uptake rate of vanillate and vanillyl alcohol added up roughly to the uptake rate of vanillin (Table 4). This is in line with a simultaneous uptake of vanillin via vanillate and a conversion of excess vanillin to vanillyl alcohol during growth on vanillin. As the uptake rate of vanillyl alcohol is lower than that of vanillin, the excretion of small amount of vanillin during growth on vanillyl alcohol was unexpected (Fig. 3). The conversion rate of ferulate and vanillate were almost equal (Table 4) and that could be the reason for intermittent trace excretion of vanillate during growth on ferulate (data not shown).

\section{Discussion}

In the present study, a bacterial strain with extensive capacity for catabolism of aromatic compounds was isolated and physiologically characterized. The method 

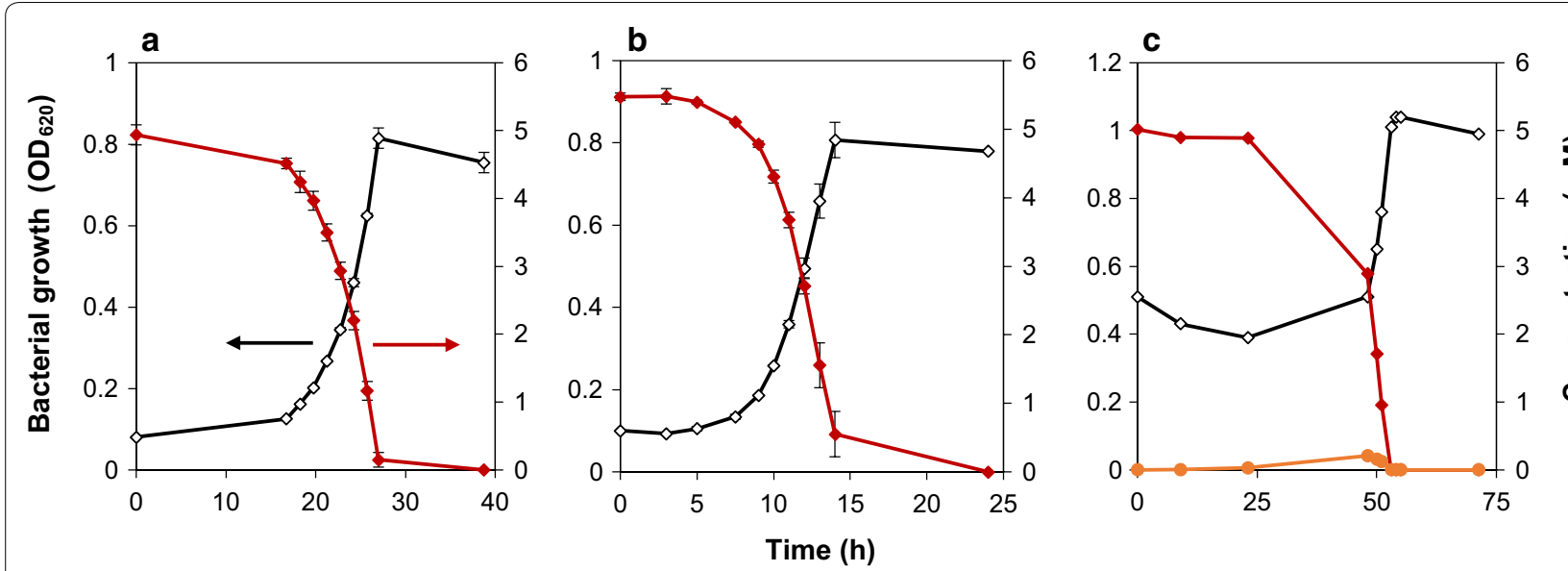

Fig. 3 Growth of Pseudomonas sp. isolate 9.1 on $\mathbf{a}$ vanillate, $\mathbf{b}$ 4-HBA and $\mathbf{c}$ vanillyl alcohol as the only source of carbon. Experiments were performed in duplicates and the standard deviations are displayed with an error bar. One representative curve is shown for the growth and consumption on vanillyl alcohol. The OD and model compounds concentration ( $\mathrm{mM}$ ) are shown in black open diamond and red closed diamond respectively. The excreted intermediate vanillin is shown in orange closed circle (Read from right axis)

Table 4 Specific growth rates, yields and uptake rates of Pseudomonas sp. isolate 9.1 on lignin model compounds

\begin{tabular}{|c|c|c|c|c|}
\hline Compounds & Specific growth rate $\left(\mathrm{h}^{-1}\right)$ & Yield $\left[g_{\text {cDw }}(\right.$ & )$]\left[g_{\mathrm{CDW}}\left(\mathrm{g}^{-1}\right)\right]$ & Specific uptake rates $\left[\mathrm{mmol}\left(\mathrm{g}_{\mathrm{CDw}} \mathrm{h}\right)^{-1}\right]$ \\
\hline Vanillin & $0.15 \pm 0.001$ & $0.09 \pm 0.001$ & $0.62 \pm 0.006$ & $3.19 \pm 0.065$ \\
\hline Benzoate & $0.30 \pm 0.019$ & $0.09 \pm 0.001$ & $0.76 \pm 0.007$ & $4.20 \pm 0.155$ \\
\hline p-Coumarate & $0.29 \pm 0.006$ & $0.11 \pm 0.005$ & $0.68 \pm 0.030$ & $2.90 \pm 0.197$ \\
\hline Ferulate & $0.18 \pm 0.001$ & $0.09 \pm 0.001$ & $0.48 \pm 0.005$ & $1.98 \pm 0.025$ \\
\hline Vanillate & $0.18 \pm 0.002$ & $0.09 \pm 0.004$ & $0.55 \pm 0.024$ & $1.95 \pm 0.032$ \\
\hline 4-HBA & $0.29 \pm 0.021$ & $0.09 \pm 0.001$ & $0.65 \pm 0.006$ & $2.87 \pm 0.360$ \\
\hline Vanillyl alcohol & $0.12 \pm 0.004$ & $0.06 \pm 0.001$ & $0.43 \pm 0.006$ & $1.67 \pm 0.021$ \\
\hline
\end{tabular}

Experiments were performed in duplicates and the standard deviations are displayed

of isolation, i.e. culture-dependent screening on either lignin or lignin-derived molecules from an interesting environment, is a widely used method to find lignin-utilizing prokaryotes (Tian et al. 2014) and proved successful also here.

Most of the bacterial isolates (five out of nine) from the enrichment cultures carried out in this study, belong to the $\gamma$-proteobacteria class, particularly to the genus Pseudomonas, the versatility of which to degrade and grow on lignin-related aromatic compounds and even technical lignins is widely acknowledged (Bandounas et al. 2011; Bugg and Rahmanpour 2015; Narbad and Gasson 1998). Three Gram-positive isolates from the Bacillaceae family were also detected by this growth-dependent method, namely Bacillus licheniformis, B. safensis and Lysinibacillus macroides. Many species of the genus Bacillus were previously found in deep-sea sediments in a similar screening carried out by Ohta et al. (2012), and most of them were also metabolically active toward lignin-related aromatic compounds. Finally, one Rhodococcus erythropolis strain, an actinomycete belonging to the high
$\mathrm{G}+\mathrm{C}$ Gram positive bacteria, was found as well. This is not surprising, since a number of rhodococci including $R$. erythropolis have been described among the most efficient bacterial lignin degraders (Ahmad et al. 2010) and are also able to metabolize the low-molecular weight compounds coming from lignin degradation (Taylor et al. 2012). Some of the bacterial isolates found in this work did not show ability to grow in liquid cultures with the model compounds utilized for their isolation (Additional file 1: Figs. S1 and S2). The initial growth on the screening plates might be due to the presence of intracellular storage compounds accumulated during the revitalization stage in rich medium.

Characterizing the aromatic metabolism, both in terms of catabolic pathways and the capacities of these pathways, is important to enable the design of efficient lignin conversion processes. The growth on low-molecular-weight lignin model compounds is relevant since the catabolism of such compounds is essential after, or along with, lignin mineralization (Bandounas et al. 2011). In the present study, six aromatic model compounds from the 
main different upper funneling pathways of lignin conversion were selected as carbon sources: vanillin, guaiacol and ferulate from the coniferyl branch; $p$-coumarate from the coumaryl branch; benzoate from the benzoyl branch and syringate from the sinapyl branch (Fig. 1). The coniferyl and coumaryl branches converge at protocatechuate (except for guaiacol which is converted to catechol), the benzoyl branch continues through catechol, whereas the sinapyl branch proceeds down to 3-O-methylgallic acid or even further to gallic acid. Protocatechuate and catechol enter the $\beta$-ketoadipate pathway ending with acetyl-CoA and succinyl-CoA, while 3-O-methylgallic acid/gallic acid undergoes ring cleavage and degrades to oxaloacetic acid and pyruvic acid. All these products either are the TCA (tricarboxylic acid) cycle intermediates or eventually enter the TCA cycle to promote cell growth. The isolate 9.1, tentatively identified as $P$. deceptionensis was able to take up four out of the six tested lignin model compounds as sole sources of carbon. The highest specific growth and uptake rates were measured for benzoate (Table 4), indicating that the benzoyl branch is the fastest of the upper funneling pathways in this isolate. The second fastest uptake occurred in the $p$-coumaryl branch with uptake rates of $p$-coumarate and 4-HBA around $2.9 \mathrm{mmol} \mathrm{g}_{\mathrm{CDW}}^{-1} \mathrm{~h}^{-1}$. The coniferyl branch operated at a somewhat lower flux rate, with uptake rates of ferulate, vanillate and vanillyl alcohol lower than $2 \mathrm{mmol} \mathrm{g}_{\mathrm{CDW}}^{-1} \mathrm{~h}^{-1}$. This might be due to the presence of phenylmethyl ether linkage in the coniferyl branch, which is comparatively difficult to breakdown (Okamura-Abe et al. 2016). No growth was obtained for syringate and guaiacol. The difficulty in metabolizing highly methoxylated substrates such as those present in the syringyl branch is most likely due to the complex enzymatic systems required for its demethylation. The $O$-demethylase systems for dimethoxylated compounds are well described in the case of Sphingobium sp. SYK6. Acetobacterium woodii, Acetobacterium dehalogenans and Moorella thermoacetica (Berman and Frazer 1992; Kaufmann et al. 1998; Naidu and Ragsdale 2001). They consist of two methyl transferases which convey the methyl groups from the aromatic substrate (e.g. veratrol, syringate) to an accepting cofactor like tetrahydrofolate $\left(\mathrm{H}_{4} \mathrm{~F}\right)$, often with the involvement of a corrinoid protein. These systems usually show relatively high substrate specificity, and also require continuous supply and enzymatic recycling of the cofactor; moreover, when a corrinoid protein is involved, spontaneous oxidation of its cobalt group can take place, and ATP-consuming enzymatic regeneration of this oxidized catalyst will be necessary (Siebert et al. 2005). Additionally, the demethylation reactions can result in the formation of formaldehyde or formic acid (Masai et al. 2007; Overhage et al. 1999), toxic intermediates that require further processing (Hibi et al. 2005), which can contribute to the slower metabolism of these compounds (Additional file 1: Figs. S3 and S4).

There was a short lag phase of approximately $15 \mathrm{~h}$ for ferulate, $p$-coumarate and benzoate (Fig. 2), necessary for adaption to the new carbon source and expression of required enzymes after prior growth on glucose (Kurosawa et al. 2015). A much longer lag phase, around $100 \mathrm{~h}$, for growth on vanillin (Fig. 2) and no growth on syringate for $200 \mathrm{~h}$, was observed. The antimicrobial effect of both compounds is well documented for many organisms. The concentration of vanillin and syringate required to inhibit the growth the Escherichia coli LY01 by $50 \%$ is 0.9 and $1.6 \mathrm{~g} / \mathrm{L}$ respectively (Zaldivar et al. 1999). The mechanism of inhibition can be either bacteriostatic or bactericidal. The increased uptake of nucleic acid stain upon exposure of $E$. coli to vanillin suggests that the integrity and stability of the cell membrane was affected, leading to cell lysis (Fitzgerald et al. 2004). In another study, the addition of syringic acid at the concentration of $\mathrm{IC}_{80}(80 \%$ inhibitory concentration), proved to destroy the membrane integrity by increasing membrane leakage by three fold (Zaldivar and Ingram 1999). However, in our case, no major cell lysis (i.e. no decrease in OD) was observed when exposed to vanillin or syringate, which suggests that the inhibition was bacteriostatic. A quite long lag phase before growth on vanillin, might explain the time required by the organism to repair the cell damage and overcome the inhibition (Rolfe et al. 2012).

Interestingly, Pseudomonas sp. isolate 9.1 while growing on some model compounds excreted certain pathway intermediates. This contrasts to previous observations with P. putida strains (Ravi et al. 2017). It appears that isolate 9.1 is not regulated to maintain the same flux throughout the pathway to the same extent as P. putida. With the exception of cis,cis-muconate, all the excreted intermediates were later consumed, thereby enabling the complete utilization of the carbon source, although in a di- or tri-auxic growth pattern. Cis,cis-muconate and catechol were excreted during growth on benzoate, but while catechol was subsequently taken up, cis,cismuconate remained unconsumed (Fig. 2c). Possibly Pseudomonas sp. isolate 9.1 lacks or has a defective version of the gene encoding the transporter involved in the uptake of cis,cis-muconate, which in Acinetobacter and other Pseudomonas strains has been identified as mucK (Williams and Shaw 1997), a member of the family 15 of MFS transporters (Pao et al. 1998). It is not clear how the accumulated cis,cis-muconate is excreted outside of the cell without a functional transporter, but there may be other transporters able to move this compound across the cell membrane with lower specificity. Cis,cis-muconate can 
be used as a precursor to adipic acid, one of the monomers in nylon-6,6 (Vardon et al. 2015) and has therefore attracted quite some interest. Bioconversion of benzoate to cis,cis-muconate was explored in P. putida KT2440JD1 (van Duuren et al. 2012). Also in this $P$. putida strain, the maximum uptake rate of benzoate was higher than the production rate of cis,cis-muconate, which is the reason for the excretion of benzoate derivatives in the cells. Excessive uptake of benzoate is also a reason for the excretion of catechol, which reduces the expression of the ben operon leading to the decreased conversion of benzoate to cis,cis-muconate (van Duuren et al. 2012).

Accumulation of catechol in the culture media might be toxic to the organism since catechol is unstable at $\mathrm{pH}$ 7 and produces reactive oxygen species. The oxidized species spontaneously form colored polymers (Subramanian and Worden 1993; Sudarsan et al. 2016; Yang et al. 2014), which give experimental problems to study catechol as a sole source of carbon in growth experiments, also in the present work.

Somewhat unexpectedly, vanillyl alcohol was excreted during growth of Pseudomonas sp. isolate 9.1 on vanillin (Fig. 2 vanillin). As vanillin is a potential inhibitor to many microorganisms, the conversion of vanillin to less toxic intermediates is quite common (Gallage and Møller 2015). In bacteria, especially pseudomonads, vanillin is normally converted to vanillate (Graf and Altenbuchner 2014; Ravi et al. 2017). However, under growing conditions, P. fluorescens B56 was able to convert vanillin to vanillate with a small amount of vanillyl alcohol being excreted (Asm et al. 1988). In addition, a genetically modified Pseudomonas strain (vanillin dehydrogenase deletion mutant) was able to produce vanillyl alcohol via ferulic acid and vanillin, when eugenol was given as a sole carbon source (Takasago Perfumery Co Ltd 1993). Although the intention of genetic modification was to produce vanillin from eugenol, the strain further converted some amount of vanillin to vanillyl alcohol, which proves the existence of such activity under certain conditions.

The conversion of vanillin to vanillyl alcohol is more common as a part of the detoxification process in eukaryotes such as Phanerochaete chrysosporium or Saccharomyces cerevisiae, (Nguyen et al. 2015; Stentelaire et al. 1997). The uptake rate of vanillin by isolate 9.1 was $3.19 \mathrm{mmol} \mathrm{g}_{\mathrm{CDW}}^{-1} \mathrm{~h}^{-1}$, whereas the uptake of vanillate was only $1.95 \mathrm{mmol} \mathrm{g}_{\mathrm{CDW}}^{-1} \mathrm{~h}^{-1}$. The excess uptake of vanillin was apparently channeled to vanillyl alcohol, which was subsequently giving rise to a diauxic growth pattern.

Another observation was that Pseudomonas $s p$. isolate 9.1 had a relatively stable stationary phase after the carbon source was depleted (Figs. 2, 3). This is in contrast to our previous work with $P$. putida KT2440, in which case there was a rapid decrease in the biomass concentration directly after the depletion of the carbon source without a stable stationary phase (Ravi et al. 2017).

In conclusion, the isolate 9.1, tentatively identified as Pseudomonas deceptionensis based on gyrB alignment, appears to possess most of the major upper funneling pathways necessary for the conversion of lignin-related aromatic compounds. Growth on model compounds does not mean that the organism will necessarily convert lignin or depolymerized lignin. However, it is a prerequisite for such conversion to occur.

Further work will show if this isolate or other bacterial strains are able to metabolize or partially convert different types of depolymerized lignin, which is necessary for the establishment of efficient processes in the future biorefineries, paving the way for a complete exploitation of the forestry and agricultural resources.

\section{Additional file}

Additional file 1. Characterization of bacterial isolates on lignin model compounds.

\begin{abstract}
Abbreviations
rRNA: ribosomal ribonucleic acid; CDW: cell dry weight; NaCl: sodium chloride; PCR: polymerase chain reaction; bp: base pairs; LB: Lysogeny Broth; rpm: revolutions per minute; OD: optical density; UHPLC: ultra high performance liquid chromatography; $\mathrm{BEH}$ : ethylene bridged hybrid; $\mathrm{MS}^{\mathrm{n}}$ : multiple stage tandem mass spectrometry; HESI: heated electrospray ionization; $\mathrm{m} / \mathrm{z}$ : mass-to-charge ratio; 4-HBA: 4-hydroxybenzoic acid; G+C: guanine and cytosine content; TCA cycle: tricarboxylic acids cycle; $\mathrm{H}^{4} \mathrm{~F}$ : tetrahydrofolate; MFS transporters: major facilitator superfamily transporters.
\end{abstract}

\section{Authors' contributions}

$\mathrm{KR}, J \mathrm{GH}, \mathrm{MGG}$ and $\mathrm{GL}$ conceived and designed the study. KR, JGH and MN performed the experiments. KR, JGH, MN, MGG and GL interpreted the experimental results. KR and JGH drafted the manuscript. MGG and $G L$ revised the manuscript. All authors read and approved the final manuscript.

\section{Author details}

${ }^{1}$ Department of Chemical Engineering, Lund University, P.O. Box 124, 221 00 Lund, Sweden. ${ }^{2}$ Department of Chemistry, Applied Microbiology, Lund University, P.O. Box 124, 22100 Lund, Sweden.

\section{Acknowledgements}

Materials for isolation of the strains reported in this study were obtained during the TREASURE project, in the Swedish Geotechnical Institute-Tuffo initiative funded by Formas (Grant No. 2014-63). They were kindly provided by Dr. Catherine Paul, Professor lan Snowball and SGU (The Geological Survey of Sweden). We would also like to thank Ola Wallberg and Basel Al-Rudainy from the Department of Chemical Engineering at Lund University for providing the lignin-containing stream samples. Finally, we thank Dr. Sofia Essén and Jens Prothmann from the Centre for Analysis and Synthesis at Lund University for helping us with the identification of unknown compounds by MS-MS analysis. This work was financially supported by the Swedish Foundation for Strategic Research through the Grant Contract RBP14-0052.

\section{Competing interests}

The authors declare that they have no competing interests.

\section{Availability of data and materials}

Pseudomonas sp. 9.1 was deposited in the DSMZ (German Collection of Microorganisms and Cell Cultures), with Accession Code DSM 105530. All the 
strains isolated in this work (see Table 1) are available for research purposes upon request.

The obtained $16 \mathrm{~S}$ rRNA and gyrB sequences from bacterial isolates were deposited in the European Nucleotide Archive (ENA), with the following accession codes: LT891931 (16S isolate 8.1), LT891932 (16S isolate 8.2), LT891933 (16S isolate 9.1), LT891934 (16S isolate 9.2), LT891935 (16S isolate 19), LT891936 (16S isolate 47.1), LT891937 (16S isolate 47.2), LT891938 (16S isolate 49), LT891939 (16S isolate 3B), LT891940 (gyrB isolate 8.1), LT891941 (gyrB isolate 9.1) and LT891942 (gyrB isolate 9.2).

\section{Consent for publication}

Not applicable.

\section{Ethics approval and consent to participate}

This article does not contain any studies with human participants or animals performed by any of the authors.

\section{Funding}

This work was financed by the Swedish Foundation for Strategic Research through the Grant Contract RBP14-0052.

\section{Publisher's Note}

Springer Nature remains neutral with regard to jurisdictional claims in published maps and institutional affiliations.

Received: 8 February 2018 Accepted: 22 February 2018

Published online: 02 March 2018

\section{References}

Abdelaziz OY, Brink DP, Prothmann J, Ravi K, Sun M, García-Hidalgo J, Sandahl M, Hulteberg CP, Turner C, Lidén G, Gorwa-Grauslund MF (2016) Biological valorization of low molecular weight lignin. Biotechnol Adv 34(8):1318-1346. https://doi.org/10.1016/j.biotechadv.2016.10.001

Ahmad M, Taylor CR, Pink D, Burton K, Eastwood D, Bending GD, Bugg TD (2010) Development of novel assays for lignin degradation: comparative analysis of bacterial and fungal lignin degraders. Mol BioSyst 6(5):815821. https://doi.org/10.1039/b908966g

Ahmad M, Roberts JN, Hardiman EM, Singh R, Eltis LD, Bugg TD (2011) Identification of DypB from Rhodococcus jostii RHA1 as a lignin peroxidase. Biochemistry 50(23):5096-5107. https://doi.org/10.1021/bi101892z

Apler A, Nyberg J, Jönsson K, Hedlund I, Heinemo S, Kjellin B (2014) Kartläggning av fiberhaltiga sediment längs Västernorrlands kust. SGU-Sveriges geologiska undersökning, Länsstyrelsen i Västernorrland

Asm H, Onozaki H, Imaseki H (1988) Vanillylamine metabolism in Pseudomonas fluorescens. Agric Biol Chem 52(11):2741-2746. https://doi.org/10.1080/0 0021369.1988 .10869155

Ayyachamy M, Cliffe FE, Coyne JM, Collier J, Tuohy MG (2013) Lignin: untapped biopolymers in biomass conversion technologies. Biomass Convers Biorefin 3(3):255-269. https://doi.org/10.1007/s13399-013-0084-4

Bandounas L, Wierckx NJ, de Winde JH, Ruijssenaars HJ (2011) Isolation and characterization of novel bacterial strains exhibiting ligninolytic potential. BMC Biotechnol 11:94. https://doi.org/10.1186/1472-6750-11-6794

Barbe V, Vallenet D, Fonknechten N, Kreimeyer A, Oztas S, Labarre L, Cruveiller S, Robert C, Duprat S, Wincker P, Ornston LN, Weissenbach J, Marlière P, Cohen GN, Médigue C (2004) Unique features revealed by the genome sequence of Acinetobacter sp. ADP1, a versatile and naturally transformation competent bacterium. Nucleic Acids Res 32(19):5766-5779. https:// doi.org/10.1093/nar/gkh910

Beckham GT, Johnson CW, Karp EM, Salvachúa D, Vardon DR (2016) Opportunities and challenges in biological lignin valorization. Curr Opin Biotechnol 42:40-53. https://doi.org/10.1016/j.copbio.2016.02.030

Berman MH, Frazer AC (1992) Importance of tetrahydrofolate and ATP in the anaerobic $O$-demethylation reaction for phenylmethylethers. Appl Environ Microbiol 58(3):925-931

Berryman D, Houde F, DeBlois C, O'Shea M (2004) Nonylphenolic compounds in drinking and surface waters downstream of treated textile and pulp and paper effluents: a survey and preliminary assessment of their potential effects on public health and aquatic life. Chemosphere 56(3):247-255. https://doi.org/10.1016/j.chemosphere.2004.02.030

Brown ME, Chang MC (2014) Exploring bacterial lignin degradation. Curr Opin Chem Biol 19:1-7. https://doi.org/10.1016/j.cbpa.2013.11.015

Brown ME, Walker MC, Nakashige TG, lavarone AT, Chang MC (2011) Discovery and characterization of heme enzymes from unsequenced bacteria: application to microbial lignin degradation. J Am Chem Soc 133(45):18006-18009. https://doi.org/10.1021/ja203972q

Bugg TD, Rahmanpour R (2015) Enzymatic conversion of lignin into renewable chemicals. Curr Opin Chem Biol 29:10-17. https://doi.org/10.1016/j. cbpa.2015.06.009

Bugg TD, Ahmad M, Hardiman EM, Rahmanpour R (2011a) Pathways for degradation of lignin in bacteria and fungi. Nat Prod Rep 28(12):1883-1896. https://doi.org/10.1039/c1np00042j

Bugg TD, Ahmad M, Hardiman EM, Singh R (2011b) The emerging role for bacteria in lignin degradation and bio-product formation. Curr Opin Biotechnol 22(3):394-400. https://doi.org/10.1016/j.copbio.2010.10.009

Camarero S, Martínez MJ, Martínez AT (2014) Understanding lignin biodegradation for the improved utilization of plant biomass in modern biorefineries. Biofuels Bioprod Biorefin 8(5):615-625. https://doi.org/10.1002/ bbb.1467

Chen YH, Chai LY, Zhu YH, Yang ZH, Zheng Y, Zhang H (2012) Biodegradation of kraft lignin by a bacterial strain Comamonas sp. B-9 isolated from eroded bamboo slips. J Appl Microbiol 112(5):900-906. https://doi. org/10.1111/j.1365-2672.2012.05275.x

Fitzgerald DJ, Stratford M, Gasson MJ, Ueckert J, Bos A, Narbad A (2004) Mode of antimicrobial action of vanillin against Escherichia coli, Lactobacillus plantarum and Listeria innocua. J Appl Microbiol 97(1):104-113. https:// doi.org/10.1111/j.1365-2672.2004.02275.x

Gallage Nethaji J, Møller Birger L (2015) Vanillin-bioconversion and bioengineering of the most popular plant flavor and its de novo biosynthesis in the vanilla orchid. Mol Plant 8(1):40-57. https://doi.org/10.1016/j. molp.2014.11.008

Graf N, Altenbuchner J (2014) Genetic engineering of Pseudomonas putida KT2440 for rapid and high-yield production of vanillin from ferulic acid. Appl Microbiol and Biotechnol 98(1):137-149. https://doi.org/10.1007/ s00253-013-5303-1

Hibi M, Sonoki T, Mori H (2005) Functional coupling between vanillate-O-demethylase and formaldehyde detoxification pathway. FEMS Microbiol Lett 253(2):237-242. https://doi.org/10.1016/j.femsle.2005.09.036

Huang XF, Santhanam N, Badri DV, Hunter WJ, Manter DK, Decker SR, Vivanco JM, Reardon KF (2013) Isolation and characterization of lignin-degrading bacteria from rainforest soils. Biotechnol Bioeng 110(6):1616-1626. https://doi.org/10.1002/bit.24833

Jiménez Jl, Miñambres B, García JL, Díaz E (2002) Genomic analysis of the aromatic catabolic pathways from Pseudomonas putida KT2440. Environ Microbiol 4(12):824-841

Kaufmann F, Wohlfarth G, Diekert G (1998) O-Demethylase from Acetobacterium dehalogenans-cloning, sequencing, and active expression of the gene encoding the corrinoid protein. Eur J Biochem 257(2):515-521

Kurosawa K, Laser J, Sinskey AJ (2015) Tolerance and adaptive evolution of triacylglycerol-producing Rhodococcus opacus to lignocellulosederived inhibitors. Biotechnol Biofuels 8:76. https://doi.org/10.1186/ s13068-015-0258-3

Makela MR, Marinovic M, Nousiainen P, Liwanag AJ, Benoit I, Sipila J, Hatakka A de Vries RP, Hilden KS (2015) Aromatic metabolism of filamentous fungi in relation to the presence of aromatic compounds in plant biomass. Adv Appl Microbiol 91:63-137. https://doi.org/10.1016/bs.aambs.2014.12.001

Martínez AT, Speranza M, Ruiz-Dueñas FJ, Ferreira P, Camarero S, Guillén F, Martínez MJ, Gutiérrez A, del Río JC (2005) Biodegradation of lignocellulosics: microbial, chemical, and enzymatic aspects of the fungal attack of lignin. Int Microbiol 8(3):195-204

Masai E, Katayama Y, Fukuda M (2007) Genetic and biochemical investigations on bacterial catabolic pathways for lignin-derived aromatic compounds. Biosci Biotechnol Biochem 71(1):1-15. https://doi.org/10.1271/ bbb.60437]

Mulet M, Lalucat J, García-Valdés E (2010) DNA sequence-based analysis of the Pseudomonas species. Environ Microbiol 12(6):1513-1530. https://doi. org/10.1111/j.1462-2920.2010.02181.x 
Naidu D, Ragsdale SW (2001) Characterization of a three-component vanillate O-demethylase from Moorella thermoacetica. J Bacteriol 183(11):32763281. https://doi.org/10.1128/jb.183.11.3276-3281.2001

Narbad A, Gasson MJ (1998) Metabolism of ferulic acid via vanillin using a novel CoA-dependent pathway in a newly-isolated strain of Pseudomonas fluorescens. Microbiology 144(Pt 5):1397-1405. https://doi. org/10.1099/00221287-144-5-1397

Nguyen TT, Iwaki A, Izawa S (2015) The ADH7 promoter of Saccharomyces cerevisiae is vanillin-inducible and enables mRNA translation under severe vanillin stress. Front Microbiol 6:1390. https://doi.org/10.3389/ fmicb.2015.01390

Ohta Y, Nishi S, Haga T, Tsubouchi T, Hasegawa R, Konishi M, Nagano Y, Tsuruwaka Y, Shimane Y, Mori K, Usui K, Suda E, Tsutsui K, Nishimoto A, Fujiwara Y, Maruyama T, Hatada Y (2012) Screening and phylogenetic analysis of deep-sea bacteria capable of metabolizing lignin-derived aromatic compounds. Open J Marine Sci 02(04):177-187. https://doi.org/10.4236/ ojms.2012.24021

Okamura-Abe Y, Abe T, Nishimura K, Kawata Y, Sato-Izawa K, Otsuka Y, Nakamura M, Kajita S, Masai E, Sonoki T, Katayama Y (2016) Beta-ketoadipic acid and muconolactone production from a lignin-related aromatic compound through the protocatechuate 3,4-metabolic pathway. J Biosci Bioeng 121(6):652-658. https://doi.org/10.1016/j.jbiosc.2015.11.007

Overhage J, Priefert H, Steinbüchel A (1999) Biochemical and genetic analyses of ferulic acid catabolism in Pseudomonas sp. strain HR199. Appl Environ Microbiol 65(11):4837-4847

Pao SS, Paulsen IT, Saier MH Jr (1998) Major facilitator superfamily. Microbiol Mol Biol Rev 62(1):1-34

Pérez-Pantoja D, De la Iglesia R, Pieper DH, González B (2008) Metabolic reconstruction of aromatic compounds degradation from the genome of the amazing pollutant-degrading bacterium Cupriavidus necator JMP134. FEMS Microbiol Rev 32(5):736-794. https://doi. org/10.1111/j.1574-6976.2008.00122.x

Pfennig N, Lippert KD (1966) Über das Vitamin B12-Bedürfnis phototropher Schwefelbakterien. Archiv für Mikrobiol 55(3):245-256. https://doi. org/10.1007/bf00410246

Picart P, Wiermans L, Pérez-Sánchez M, Grande PM, Schallmey A, Domínguez de María P (2016) Assessing lignin types to screen novel biomassdegrading microbial strains: synthetic lignin as useful carbon source. ACS Sustain Chem Eng 4(3):651-655. https://doi.org/10.1021/ acssuschemeng.5b00961

Priyadarshinee R, Kumar A, Mandal T, Dasguptamandal D (2016) Unleashing the potential of ligninolytic bacterial contributions towards pulp and paper industry: key challenges and new insights. Environ Sci Pollut Res Int 23(23):23349-23368. https://doi.org/10.1007/s11356-016-7633-x

Ramachandra M, Crawford DL, Hertel G (1988) Characterization of an extracelIular lignin peroxidase of the lignocellulolytic actinomycete Streptomyces viridosporus. Appl Environ Microbiol 54(12):3057-3063

Ravi K, Garcia-Hidalgo J, Gorwa-Grauslund MF, Liden G (2017) Conversion of lignin model compounds by Pseudomonas putida KT2440 and isolates from compost. Appl Microbiol Biotechnol 101(12):5059-5070. https://doi. org/10.1007/s00253-017-8211-y

Rinaldi R, Jastrzebski R, Clough MT, Ralph J, Kennema M, Bruijnincx PCA, Weckhuysen BM (2016) Paving the way for lignin valorisation: recent advances in bioengineering, biorefining and catalysis. Angew Chem Int Ed 55(29):8164-8215. https://doi.org/10.1002/anie.201510351

Rodriguez A, Salvachúa D, Katahira R, Black BA, Cleveland NS, Reed M, Smith H, Baidoo EEK, Keasling JD, Simmons BA, Beckham GT, Gladden JM (2017) Base-catalyzed depolymerization of solid lignin-rich streams enables microbial conversion. ACS Sustain Chem Eng 5(9):8171-8180. https://doi. org/10.1021/acssuschemeng.7b01818

Rolfe MD, Rice CJ, Lucchini S, Pin C, Thompson A, Cameron AD, Alston M, Stringer MF, Betts RP, Baranyi J, Peck MW, Hinton JC (2012) Lag phase is a distinct growth phase that prepares bacteria for exponential growth and involves transient metal accumulation. J Bacteriol 194(3):686-6701. https://doi.org/10.1128/jb.06112-11

Salvachúa D, Karp EM, Nimlos CT, Vardon DR, Beckham GT (2015) Towards lignin consolidated bioprocessing: simultaneous lignin depolymerization and product generation by bacteria. Green Chem 17(11):4951-4967. https://doi.org/10.1039/c5gc01165e
Sambrook J, Russell D (2001) Molecular cloning: a laboratory manual. Cold Spring Harbor Laboratory Press, Cold Spring Harbor

Schwarz M, Rodriguez CM, Guillen DA, Barroso CG (2009) Development and validation of UPLC for the determination of phenolic compounds and furanic derivatives in Brandy de Jerez. J Sep Sci 32:1782-1790

Shi Y, Chai L, Tang C, Yang Z, Zhang H, Chen R, Chen Y, Zheng Y (2013) Characterization and genomic analysis of kraft lignin biodegradation by the beta-proteobacterium Cupriavidus basilensis B-8. Biotechnol Biofuels 6(1):1. https://doi.org/10.1186/1754-6834-6-1

Siebert A, Schubert T, Engelmann T, Studenik S, Diekert G (2005) VeratrolO-demethylase of Acetobacterium dehalogenans: ATP-dependent reduction of the corrinoid protein. Arch Microbiol 183(6):378-384. https://doi. org/10.1007/s00203-005-0001-8

Stentelaire C, Lesage-Meessen L, Delattre M, Haon M, Sigoillot JC, Ceccaldi BC, Asther M (1997) By-passing of unwanted vanillyl alcohol formation using selective adsorbents to improve vanillin production with Phanerochaete chrysosporium. World J Microbiol Biotechnol 14(2):285-287. https://doi. org/10.1023/a:1008811019693

Subramanian R, Worden RM (1993) Kinetics of growth and catechol production by Bacillus stearothermophilus BR321. Appl Biochem Biotechnol 39(1):509-520. https://doi.org/10.1007/bf02919014

Sudarsan S, Blank LM, Dietrich A, Vielhauer O, Takors R, Schmid A, Reuss M (2016) Dynamics of benzoate metabolism in Pseudomonas putida KT2440. Metab Eng Commun 3:97-110. https://doi.org/10.1016/j. meteno.2016.03.005

Suman SK, Dhawaria M, Tripathi D, Raturi V, Adhikari DK, Kanaujia PK (2016) Investigation of lignin biodegradation by Trabulsiella sp. isolated from termite gut. Int Biodeterior Biodegradation 112:12-17. https://doi. org/10.1016/j.ibiod.2016.04.036

Takasago Perfumery Co Ltd (1993) Preparation of vanillin, coniferyl-alcohol and -aldeyhde, ferulic acid and vanillyl alcohol by culturing mutant belonging to Pseudomonas genus in presence of eugenol which is oxidatively decomposed. Japanese patent application Kokai Number 227980

Taylor CR, Hardiman EM, Ahmad M, Sainsbury PD, Norris PR, Bugg TD (2012) Isolation of bacterial strains able to metabolize lignin from screening of environmental samples. J Appl Microbiol 113(3):521-530. https://doi. org/10.1111/j.1365-2672.2012.05352.x

Tian JH, Pourcher AM, Bouchez T, Gelhaye E, Peu P (2014) Occurrence of lignin degradation genotypes and phenotypes among prokaryotes Appl Microbiol Biotechnol 98(23):9527-9544. https://doi.org/10.1007/ s00253-014-6142-4

van Duuren JB, Wijte D, Karge B, dos Santos VA, Yang Y, Mars AE, Eggink G (2012) $\mathrm{pH}$-stat fed-batch process to enhance the production of cis,cismuconate from benzoate by Pseudomonas putida KT2440-JD1. Biotechnol Prog 28(1):85-92. https://doi.org/10.1002/btpr.709

Vardon DR, Franden MA, Johnson CW, Karp EM, Guarnieri MT, Linger JG, Salm MJ, Strathmann TJ, Beckham GT (2015) Adipic acid production from lignin. Energy Environ Sci 8(2):617-628. https://doi.org/10.1039/ c4ee03230f

Williams PA, Shaw LE (1997) mucK, a gene in Acinetobacter calcoaceticus ADP1 (BD413), encodes the ability to grow on exogenous cis,cis-muconate as the sole carbon source. J Bacteriol 179(18):5935-5942

Xu C, Arancon RAD, Labidi J, Luque R (2014) Lignin depolymerisation strategies: towards valuable chemicals and fuels. Chem Soc Rev 43(22):74857500. https://doi.org/10.1039/C4CS00235K

Yamamoto S, Harayama S (1995) PCR amplification and direct sequencing of gyrB genes with universal primers and their application to the detection and taxonomic analysis of Pseudomonas putida strains. Appl Environ Microbiol 61(3):1104-1109

Yang J, Cohen Stuart MA, Kamperman M (2014) Jack of all trades: versatile catechol crosslinking mechanisms. Chem Soc Rev 43(24):8271-8298. https:// doi.org/10.1039/c4cs00185k

Yoon S-H, Ha S-M, Kwon S, Lim J, Kim Y, Seo H, Chun J (2017) Introducing EzBioCloud: a taxonomically united database of 165 rRNA gene sequences and whole-genome assemblies. Int J Syst Evol Microbiol 67(5):1613-1617. https://doi.org/10.1099/ijsem.0.001755

Zaldivar J, Ingram LO (1999) Effect of organic acids on the growth and fermentation of ethanologenic Escherichia coli LY01. Biotechnol Bioeng 66(4):203-210 
Zaldivar J, Martínez A, Ingram LO (1999) Effect of selected aldehydes on the growth and fermentation of ethanologenic Escherichia coli. Biotechnol Bioeng 65(1):24-33
Zhao C, Xie S, Pu Y, Zhang R, Huang F, Ragauskas AJ, Yuan JS (2016) Synergistic enzymatic and microbial lignin conversion. Green Chem 18(5):1306-

1312. https://doi.org/10.1039/c5gc01955a
Submit your manuscript to a SpringerOpen ${ }^{\ominus}$ journal and benefit from:

- Convenient online submission

- Rigorous peer review

- Open access: articles freely available online

- High visibility within the field

- Retaining the copyright to your article

Submit your next manuscript at $\gg$ springeropen.com 